Vol. 4, No. 2, 2017

https://doi.org/10.23939/eem2017.02.023

UDC 657.21:657.41/45

\author{
O. Lemishovska
}

$\mathrm{PhD}$ in Economics, Associate Professor

Lviv Polytechnic National University

\title{
FUNCTIONAL PURPOSE AND APPROACHES TO BUILDING ACCOUNT PLANS IN THE HISTORICAL RETROSPECTIVE
}

\begin{abstract}
The contents and function of the account plan in the organization of accounting, principles of systematization of classification groups of accounts in it are disclosed. The historical origins of the plan of accounts in accounting science and its evolution are presented. The key factors of influence on the principles and basic principles of constructing an account plan at different historical stages of accounting science are analyzed. The reasonableness of the scientific classification of accounts and disadvantages when forming accounts in the historical past has been analyzed. The expediency of conducting in-depth researches of previously formulated scientific developments concerning principles and approaches to the formation of the account plan and the use of their separate aspects in modern researches has been argued.
\end{abstract}

Key words: history of formation of the accounting, development of the accounting, classification, grouping, plan of accounts.

\section{Formulation of the problem}

In accordance with its purpose, the plan of accounts serves as the basis for accounting, and determines the order of accumulation of the systematized information required in the specific economic environment for internal and external users for making managerial decisions. The basis for constructing an invoicing plan in all historical periods was the circulation of economic resources and sources of their formation (capital) of the subject of economic activity. Formulated according to different principles and approaches, the plans of accounts had a significant impact on the evolution and development of certain areas of accounting science.

The content of the principles of building an account plan follows from the traditional functions of accounting information - to meet the information needs of different users, to provide the possibility of an objective compilation of defined forms of accounting in a particular historical period and for a particular economy. Setting and structuring accounts is an important aspect for the mutual reconciliation of the indicators of a separate enterprise with the method of information disclosure of general economic processes. Therefore, his substantiation on the agreed basis with the system of national accounts is important.

Modern methodical techniques for constructing a plan of accounts acquired in the process of historical development of the balance study, accounting theories and the development of existing systems of accounting for the present. That is why the scholars recognize that it is impossible to objectively disclose the current value of the chart of accounts to achieve the objectivity of the accounting data and the representation of the reliability of information about assets and capital in public financial reporting without analyzing the principles and approaches formulated in different historical periods for the construction of accounts plans.

The analysis of the latest research and publications shows a rather high interest of scholars in the historical achievements of the development of the Accounting Plan, approaches to its structuring and content. The importance of the selected principles, rational and scientifically-based construction of accounting in a systematic list (plan of accounting), as noted by Ya.V. Sokolov, is due to the fact that "accountancy is substantive in nature, which allows applying the methodology of accounting to any economy" [1, p. 382]. The significance of the research principles and basics used in the evolution of accounting science for the formation of the accounts for a specific economic 


\section{O. Lemishovska}

environment is related to the way in which A. N. Kuzminskyi stressed, that "in separate branches of the national economy on the basis of a single plan of accounts, taking into account the specifics of their activities, develop their accounts" [2, p. 171].

Scientists mostly hold the view on the importance of research into the evolution of the plan of accounts, the significance of their results for the current needs of adapting the accounting system and financial reporting to the conditions of the modern economy. In this context, N. V. Osadchuk notes that "the issue of creating, improving and implementing the plans of accounting in the world has long been paid close attention of scientists and specialists in order to ensure reliability and confidence in accounting, improving its management function, the introduction of an effective system of taxation on its basis" [3, p. 262]. The main accent of the significance of historical research of this element of the accounting method is the analysis of the principles and approaches to ordering accounts in it, their appointment in the accounting system and the methods of displaying information on them.

Proceeding from the above, and also similar conclusions in the publications on this direction, the authors, proving the relevance of research on the analysis of the evolution of the plan of accounts, its content and purpose, indicate that even today "the issue of rational construction of the Accounts plan is debatable and not fully studied" [4, p. 7]. In addition, K. P. Borymska notes that "the lack of a systematic approach to the consideration of directions for the development of an account plan" [5, p. 37]. Therefore, the conclusions of the overwhelming majority of studies and publications that reveal the evolution of the principles of building an account plan determine the need for an in-depth study of the principles of constructing multi-type account plans for the validity of this element of the accounting method in the modern development of the accounting system.

The purpose of the article is to consider and systematize the principles of constructing a plan of accounts at different stages of accounting knowledge, the development of individual scientific theories or paradigms, and the formulation of proposals on the feasibility of using certain principles and approaches for using contemporary developments of a bill adapted to real economic conditions.

\section{Presentation of the main research material.}

The emphasis of the development of an account plan is particularly relevant to the modern accounting practices of large corporations, the specifics of which requires the construction of an autonomous accounting system. It is the account plan that is the basic condition for the development of the accounting system for such entities. The doctrine of accounts and their consolidation into a specific format (plan) in modern accounting science is insufficiently in demand. Despite the theoretical significance of the accounts for the main concepts of accounting and balancing in modern accounting science, this aspect is pushed to the background.

Under the plan of accounts refers to their grouping by economic content, purpose and structure in a systematic list [6]. Problems of development and implementation in the conditions of functioning of modern enterprise accounts plans in order to develop the accounting system itself in modern science is still given considerable attention. This is due to the need to provide financial reporting with relevant indicators, the need to strengthen managerial functions based on the information formed on these accounts.

At the stage of the birth of accounting science was the decisive account and their double entry. In the future, there was a need to classify invoices with scientific justification of each class. Beginning the practice of using the plan of accounts was characterized by the fact that each accountant in his own enterprise independently formed the plan, so for several centuries, accountants could not even imagine that you can take a plan of accounts from another company and use it on its own [5]. In the field of internal organization of accounting, account plans created opportunities: to identify accounts with financial reporting items, ensuring the logic of its construction and the convenience of its compilation, to design model documents, forms of reporting, to disclose accounting terminology.

In the historical research of the evolution science of accounting it is believed that the founder of the accounts was E. Degrange, who in 1795 offered a single plan of accounts, bringing all accounts to five. Only small enterprises could satisfy the plan of accounts of this format. Therefore, the Belgian author A. Godefrua in 1864 proposed such a component of the organization of accounting by reducing all the accounts to six groups: 1) non-current assets; 
2) expenses; 3) inventories; 4) settlements; 5) the owner's accounts (capital, reserves, profits or losses, etc.); 6) cash and securities.

The first classifications of accounts bind them with a substantive and binding law (without any other signs), then the classification was based on mixed features (legal, economic, structural). At the same time allocated capital accounts, values, third parties. They were further developed in the early twentieth century and influenced modern approaches. In addition, accounts were divided into active and passive, as well as to budget accounts (income and expenses). Subsequently, the development of this classification led to the allocation of classification groups of accounts: "inventory, costing, distributive, operating, transit" [7]. Important in this was the classification of accounts given by L. Pacioli, who once wrote: "The account - no more than an appropriate procedure, established by the merchant, with the successful application of which he receives information about all his affairs and whether they are successful". Synthesis of the views of Italian and French accountants leads to the construction of an account system, on the one hand, taking into account accounting objects for other management purposes. The chart of accounts should be based on the classification of accounts. A plan built outside of the classroom leads to a clutter of data, and as a consequence, before receiving unsystematic and non-effective information.

In different historical periods, the scientists contributed to the development of plan of accounts by various principles regarding: the balance sheet (O. Rudanovsky), the place of balance (I. Cher), the completeness of information (Zh. Savari, J. Cherboni, V. Paliy), a business entity (R. Delaport), mobility (E. Schmalenbach), economic content (M. Kiparisov, M. Leontiev), the conventionality of assessments and their relation to the objectives of economic analysis (Zh. B. Dumarshche) [8, p. 50].

By the beginning of the twentieth century, all the account plans were focused on the formation of accounting information for the purposes of financial reporting. Plans of this type did not take into account the process of capital turnover, as well as the mechanism for comparing income and expenditure. In 1927 professor at Kiel University E. Schmalenbach justified ways to overcome these shortcomings, a means to improve the plan, the necessity of the plan of accounts was not substantiated on the basis of which balance sheets are formed, but a document combining production and trade accounting [9].

E. Schmalenbach interconnected the capital turnover and the decimals principle, his plan was a matrix of $10 \times 10$, and each element of the matrix contained 10 accounts. Such a plan of accounts allowed to freely open up to 1000 accounts per enterprise. The basis of such a plan was the idea of achieving equality in enterprises in the organization of production and, above all, industrial accounting. The approach of E. Schmalenbach was inherent in monism - the traditional German association in a single system of production and trade accounting. The only billing plan consisted of ten classes, grouped by several features: turnover of accounts K1 (including static, fixed accounts), monetary K2 (dynamic, "external" for accounting cash, currency, checks, bills, calculations), costing K3 (dynamic, to ensure the accounting process - the calculation of cost, calculation of financial results.

In the construction of the accounts individually note the theory of the French scientist P. Garnier, according to which the classification of facts of economic activity determines the classification of accounts. The basis of the theory is that "the classification can be constructed either artificially, or to execute its description objectively in the given accounts, in the latter case it will be natural, in the same way as D. Mendeleev's table, and due to this, it will be possible to open those accounts which not yet known accounting". According to his theory, all accounts P. Garnier divided into two groups: balance accounts (assets - active and sources - passive) and management accounts (productive - costs and revenues of the enterprise).

It is important to classify accounts on the evolutionary grounds of M. Blatov [7, p. 286], according to which each subsequent group of accounts was considered as the development of the previous one. So, historically groups consist of the following accounts: inventory, personal; costing distributive operational; liquidation transit Each of their kind has a certain detail. Yes, "inventory accounts are opened by type of property or its custodians; personal - for reflection of settlements with any legal entities and individuals: debtors and creditors; costing - for the consistent accumulation 


\section{O. Lemishovska}

of expenses in the process of formation of assets; distributions take into account temporary amounts that are subject to distribution among other accounts; operational opens to reveal the results of one operation, separated from others or their groups; liquidation - for accounting and comparison of projected and actual costs or predicted and actually received profits; transit accounts - to distinguish from the general list of operations and records in one or another of their groups, which is not allocated during normal accounting" [10].

Now in the world practice, the most famous are the three main directions that are used when constructing bill plans:

- matrix-accounts are divided into classes and groups, which allocate subclasses, groups of accounts and accounts themselves;

- linear - provides a sequential description of the nomenclature of synthetic accounts, grouped (without the use of sub-accounts);

- hierarchical - provides a hierarchy of subaccounts.

In the countries of the Anglo-American accounting system and at present there is no single plan of accounts. Administration of companies from Great Britain, USA, Canada, Japan, Estonia, etc. themselves form the most appropriate plan for themselves. In individual countries (France, Germany, Russia, Ukraine, Portugal, Spain, Guinea-Bissau, etc.) there are uniform national plans of accounts used by all enterprises.

With the development of financial accounting, in 1960-1980 pp. Three regional accounts were created: the EU, the Organization of African Unity, and the Latin American states.

First determine accounting as a management function and an informational source of decisionmaking, including external users They are based on international and national standards, and also take into account the effect of legal laws. They have the following features in their baseline:

- developed in accordance with the 4th EU Directive, which establishes common standards and requirements for the countries of the community for each item of the balance sheet and profit and loss account;

- act as the basis for the creation of a regional accounting system of European states;

- take into account the requirements of the Commercial Code, which defines the list of mandatory reporting registers used by economic entities;

- are based on the norms and regulations of the tax codes regulating the methods of depreciation of fixed capital, the inventory of balance sheet items, the creation of reserves and the determination of taxable profits, etc.;

- comply with the legislation, which provides for the organization of accounting and control, depending on the form of ownership, types of enterprises and their sizes.

National accounts of EU countries are based on the principles of carrying out the control and audit processes and accounting standards of the International Federation of Accountants and the European Community of Experts on Economic and Financial Accounting. Unions of Chartered Accountants, Auditors and Commissioners of Accounting in each EU country decide on the extent to which international standards are applicable.

The idea of creating an account plan in countries with Anglo-American influence on accounting development was often identified with the development of centralization principles inherent in a planned-regulated economy. However, in this regard, the purpose of E. Shmalenbach was different: in contrast to the Taylorism and centralization of production, he was guided by the fact that the proposed chart of accounts would be used as a tool for decision-making in a free market economy.

In 1927, the Association of German Machine-Building Enterprises published a plan of accounts of the Weimar Republic. It was a simplified version of the billing plan proposed by E. Schmalenbach. In the late 30's of XX century government regulation of the economy in Germany was decisive, and therefore the introduction of a single plan of accounts was inevitably inevitable. This is due to the fact that state controllers should have full information about the activities of any organization. In connection with this in 1937 was adopted a mandatory plan of accounts. In first place in the importance of accounts in the accounting system, it was not trading (financial), and production records. This chart of accounts also relied heavily on the development of $E$. Schmalenbach. The German chart of accounts (1937) became the basis for the accounts of Sweden (1942), Holland (1944), Poland (1942), 
Hungary (1943) and Greece (1944). At the same time, it should be noted that in Belgium (1944) a plan of accounts, focused on the balance principle of I. Sher, and not on the principle of the capital turnover of E. Schmalenbach, was introduced. In general, the construction of a chart of accounts on the principle of capital turnover proposed in the works of E. Schmalenbach, prevailed in almost all countries of continental Europe.

After the Second World War in the economic activity of countries and companies of Europe, the American capital began to gain decisive value. Together with this was recognized and AngloAmerican approach to accounting. Perhaps this influence would not have been so significant if not one of the drawbacks of E. Shmalenbach's plan: the plan of accounts, which simultaneously covers accounting and management accounts, leads to a breach of commercial secrecy. Around this issue, the largest discussions among critics of the bill of accounts of E. Schmalenbach were unfolded. Thus, V. Le Kutr wrote that in the German account accounting records of 1937 much attention was paid to management accounting, which led to a decrease in the significance of financial accounting.

In Switzerland, K. Kefer (1943-1946), while developing his own account plan, developed similar ideas, laying the foundation for only financial accounting. This chart of accounts reflected the theory that it was based on four main accounts. These accounting accounts were subject to analytical breakdowns: Assets, Liabilities, Expenses, Profits. Subsequently, the idea of four accounts was developed by the French author P. Garnier. It should be noted that the plans of the accounts of O. Brad, K. Kefer and P. Garnier focused on the possibility of consolidating financial statements.

Financial accounting includes, as a rule, 7-8 classes of accounting accounts, while in all countries, balance accounts are grouped into 5 classes: capital accounts, fixed assets, intangible and financial assets, inventories and work in progress, calculations and financial results. The bills for the cost-issue system are from 2 to 3 classes; most often it accounts for the cost of items, income by type. In separate countries, an independent class "Results of Accounts" is allocated.

In the plans of accounts also establishes a certain connection between classes. So, in the French accounting account, in the class 6 "Expense reports", the accounts are placed in a similar manner to the accounts of class 7 "Income accounts". For example, account 66 "Financial expenses" in class 6 corresponds to account 76 "Financial income" in class 7.

Expense and revenue accounts (have corresponding accounts of the second and subsequent orders, which account for expenses and revenues, based on their economic nature and nature. At the same time, the accounts are grouped in such a way as to allow them to determine the production, financial and extraordinary (extraordinary) result.

It should be emphasized that in most national accounts there is no class "Profit and Loss Account and Profit Profit". This is due to the fact that, in accordance with international norms, the balance is disclosed after the distribution of financial results, that is, taking into account the decisions already taken on the use of the balance on the account "Results for the year" and the balance of "Retained earnings".

In addition to the above, it should be noted that although the plans of the accounts of the 12 participating countries are very similar in general, there are some differences between them, which are usually caused by national peculiarities and traditions. The plans for the accounts of the Latin American states are shaped by the characteristic feature of the Anglo-American accounting system, which does not have the generally accepted national accounts plans. For these countries, the following features in the accounting accounting plans used are typical:

- availability of two independent accounting departments - financial and managerial;

- the chart of accounts, like most EU Member States' accounts, is based on a cost-issue method with a constant emphasis on accounting for the final result.

- direction of the purpose of the accounting system for the operative determination of financial results.

- significant integration of planning and accounting at the level of financial and managerial accounts.

In accordance with this definition of financial results is carried out on the basis of grouping the cost of elements with a clear separation of value added. 


\section{O. Lemishovska}

The lack of a single chart of accounts does not mean that anarchy prevails in the countries of the Anglo-American accounting system in this area. All professional account plans are based on certain principles, on the basis of which each company independently justifies the expedient and adequate account plan. Thus, in the USA, all accounts are divided into six main groups: Assets, Liabilities, Equity (capital of company owners), Profits, Expenses, Taxes.

\section{Conclusions}

In the modern information and intellectual economy, the specifics of the activities of each economic system (companies, corporations, enterprises), the structure of its economic resources and components, and the criteria for determining the efficiency of functioning become important. The given and determines the need for an organization for an individual entity accounting system. In theoretical studies the necessity of development and additional introduction of accounting subsystems of a new type (actuarial, prognostic, and strategic) or types of accounting is formulated. Regardless of content and functional orientation, a new version of the accounting system should be based on the plan of accounts, combining it accounts of financial and managerial accounting.

Based on the specifics of the functioning of modern enterprises, it is clear that the unification of both general classes of accounts and the class of accounts of management accounting is complex. From this perspective, it is evident that for the organization of the accounting system, each enterprise should develop its own chart of accounts. Therefore, the principles of its construction, in particular the historical experience of the formulation and practical testing of multitype accounts, the results of their analysis and the assessment of their level of validity by modern researchers, are at the forefront.

On the basis of the analysis of the development of accounting plans there is a lack of clear formalization of the principles of structuring the format of the accounts, and therefore the formulation and solution of the problem in this article is directed at substantiation of expediency of further researches made in the historical past approaches to the development of multi-type plans of accounts.

\section{References}

1. Sokolov, Ja. V., (1991). Ocherki po istorii buhgalterskogo ucheta [Essays on the History of Accounting]. Moscow: Finansy i statistika. [in Russian]

2. Kuz'minskij, A. N., (1990). Teorija buhgalterskogo ucheta [Accounting Theory]. Kyiv: Vishha shkola. [in Ukrainian]

3. Osadchuk, N. V. (2007). Development of the Ukrainian accounting accounting plan for the tasks of operational management of the enterprise. Trudbl Odesskoho polytekhnycheskoho unyversyteta [Proceedings of the Odessa Polytechnic University],1(27), 262-265. [in Ukrainian]

4. Mykhalevych, S. (2011), The plan of accounting accounts and the need for its improvement. Bukhhalterskyi oblik $i$ audyt [Accounting and Audit], 7, 7-9. [in Ukrainian]

5. Borymska, K. P., (2009). Plan of accounting accounts as an integrated accounting model: approaches to construction.Visnyk ZhDTU [Bulletin of the ZhDTU], 3 (53), 37-43. [in Ukrainian]

6. Veryha, Iu. A. (2010). Plan rakhunkiv bukhhalterskoho obliku [Account accounting plan]. Kyiv: Tsentr uchbovoi literatury [in Ukrainian]

7. Blatov, N. A. (1930). Balansovedenie [Balance records]. Leningrad: Ekonomicheskoe obrazovanie. [in Russian]

8. Sokolov, Ja. V., (2010). Buhgalterskij uchet kak summa faktov hozjajstvennoj zhizni [Accounting as the sum of facts of economic life]. Moscow: Magistr: INFRA-M. [in Russian]

9. Shmalenbah, E. (1928). Schetnyi plany ( opyt unificirvanoj klasifikacii schetov) [Scorecard Plans (experience of the unificarized accounts classification): translated from german]. Moscow: Jekonomicheskoe obrazovanie. [in Russian]

10. Kaliuha Ie. V. (2014). Approaches to the classification of accounting accounts: the historical aspect. Ekonomichni nauky, Seriia "Oblik $i$ finansy" [Economic sciences, Series "Accounting and Finance"], 11 (41), Ch. 2, 131-143. [in Ukrainian] 